International Journal of Business Management and Economic Review

Vol. 4, No. 01; 2021

ISSN: 2581-4664

\title{
THE EFFECT OF PRODUCT QUALITY AND CUSTOMER TRUST ON CUSTOMER SATISFACTION AND ITS IMPLICATIONS ON CUSTOMER LOYALTY PT. BANK ACEH SYARIAH, JANTHO BRANCH, ACEH BESAR DISTRICT
}

\author{
Ian Fahmi,Sorayanti Utami and T. Meldi Kesuma \\ Department of Management, Universitas Syiah Kuala, Indonesia \\ http://doi.org/10.35409/IJBMER.2021.3225
}

\begin{abstract}
This research aimed to analyze the effect of product quality (P-Quality) and customer trust (CTrust) on customer satisfaction (C-Satisfaction) and its impact on customer loyalty (CLoyalty).The sampling technique used was cluster sampling with the size of respondents as manyas 150 customers. The data analysis technique used was SEM (Structural Equation Model). The results proved that P-Quality significantly affected C-Satisfaction; C-Trust significantly affected C-Satisfaction; P-Quality significantly affected C-Loyalty; C-Trust significantly affected C-Loyalty; C-Satisfaction significantly affected customers loyalty; P-Quality significantly affected C-Loyalty through C-Satisfaction, and; C-Trust significantly affected CLoyalty through C-Satisfaction. In the model, the C-Satisfaction acted as a partial mediator for both independent variables in affecting the C-Loyalty. These findings make a positive contribution to the development of science, especially in the field of marketing science. The novelty of the research lies in the combination of causality theory so that it becomes a model in this study. Further research should be able to further develop this tested research model, by adding moderate variables such as religiosity or type of work (businessman or not), which are an interesting issue in the use of Bank Aceh Syariah. The findings of this model are also useful as a reference for regulators at Bank Aceh Syariah. To increase consumer loyalty, Bank Aceh Syariah should improve P-Quality and consumer confidence, to increase the level of consumer satisfaction so that it has an impact on their loyalty to Bank Aceh Syariah.
\end{abstract}

Keyword: Product Quality, Customer Trust, Customer Satisfaction, Customer Loyalty.

\section{INTRODUCTION}

The banking industry is currently very competitive, with various efforts made by companies engaged in the banking sector to survive in this competition. The presence of private banks makes competition in the banking sector even more attractive, where private banks also offer a wide selection of banking products or services that are the same and not less competitive than those offered by state banks. To be able to survive in this competitive business market, it is very important that every company must pay attention to it, including PT. Bank Aceh Syariah, the Sharia bank owned by Province Government of Aceh, Indonesia, especially its Jantho located in Aceh Besar District, namely by always paying attention to and maintaining C-Loyalty.

Customer loyalty (C-Loyalty) is not something that is easily created and maintained, 


\section{International Journal of Business Management and Economic Review}

Vol. 4, No. 01; 2021

ISSN: 2581-4664

therefore if PT. Bank Aceh Syariahwants to create and maintain C-Loyalty, what needs to be done is by increasing customer satisfaction (C-Satisfaction), because satisfaction is the most dominant and key factor in creating loyalty (Munari, Ielasi, \& Bajetta, 2013).C-Loyalty can also be obtained by creating customer trust (C-Trust) and also improving product quality (P-Quality). $\mathrm{C}$-Trust in a bank is important in creating loyalty because when a customer has full trust in a bank, the customer will tend to be loyal to the bank (Lubis, 2015). C-Loyalty to a bank is largely determined by the quality of the products offered by the bank because basically P-Quality can be said to be a strong foundation for building C-Loyalty(Oghojafor, Ladipo, Ighomereho, \& Odunewu, 2014).

Based on the description previously explained, it is known that C-Loyalty can be affected by P-Quality, C-Trust, and C-Satisfaction. Nevertheless, there are differences in the results of research conducted by previous researchers (research gap). The results of previous researchfound that P-Quality(Elidawati, Yasri, \& Idris, 2018), C-Trust(Majid, 2013), and CSatisfaction(Afeshat \& Alola, 2018)significantlyaffectsC-Loyalty. Meanwhile,there are also research results which found that P-Quality(Sirait, Lubis, \& Gultom, 2020), C-Trust(Aprilia, Maming, \& Pakki, 2020), and C-Satisfaction(WeiMeng, 2019)not significantly affect C-Loyalty. Thus, the purpose of this researchis to determine whether P-Quality, C-Trust, and C-Satisfaction have contributed to increasing C-Loyalty and whether C-Satisfaction acts as a mediation between the effect of P-Quality and C-Trust on C-Loyalty.

\section{LITERATURE REVIEW}

C-Loyalty is a positive attitude and commitment that a customer has towards a bank to keep subscribing to the bank(Ridwan, Moeljadi, Sunaryo, \& Sudjatno, 2017).Then, C-Satisfaction can be said to be a summary of the psychological state that comes from the comparison between experiences after using a product with expectations before using the product(Lubis, 2015).Next, $\mathrm{C}$-Trust can be defined as customer awareness of the performance expectations of a product based on experience and trust which are manifested in the form of attitudes(Utami, 2015).Furthermore, (Kotler \& Keller, 2018) defined P-Quality as the totality of the features and characteristics of a product that can satisfy consumer needs, both expressed and implied.

The results of research conducted by (Hidayat \& Akhmad, 2016) and (Ling \& Mansori, 2018 ) found that P-Quality has a positive and significant effect on C-Satisfaction. Then, the results of research conducted by (Sugiati, Thoyib, Hadiwidjoyo, \& Setiawan, 2013) and (Iqbal, Murni, \& Sulistyowati, 2018) found that customer value has a positive and significant effect on C-Satisfaction.

The results of research conducted by (Afeshat \& Alola, 2018) found that C-Satisfaction had a significant effect on C-Loyalty. Then, other research results found that P-Quality(Wandi, Zainal, Arafah, Subagja, \& Saad, 2020) and C-Trust(Hidayat, Akhmad, \& Machmud, 2015) had a significant effect on C-Satisfaction. Furthermore, other research results found that PQuality(Elidawati et al., 2018) and C-Trust(Majid, 2013) had a significant effect on C-Loyalty. The results of research conducted by (Sirait et al., 2020) found that P-Quality had a significant effect on C-Loyalty indirectly through C-Satisfaction and also the results of research conducted by (Aprilia et al., 2020) found that C-Trust had a significant effect on C-Loyaltyindirectly through C-Satisfaction. 


\section{International Journal of Business Management and Economic Review}

Vol. 4, No. 01; 2021

ISSN: 2581-4664

Based on the above review of literature, the research hypothesis is determined as follows:

1) P-Qualitysignificantly affectedC-Satisfaction

2) C-Trustsignificantly affected C-Satisfaction

3) P-Qualitysignificantly affectedC-Loyalty

4) C-Trustsignificantly affectedC-Loyalty

5) C-Satisfactionsignificantly affectedcustomers loyalty

6) P-Qualitysignificantly affectedC-Loyaltythrough C-Satisfaction

7) C-Trustsignificantly affectedC-Loyaltythrough C-Satisfaction

\section{METHOD}

The population in this researchwas all customers of PT. Bank Aceh Syariah, Jantho Branch, Aceh Besar District, while the number of sample in this study was 150customers selected by cluster sampling.The research data were obtained through the dissemination of questionnaires and analyzed by structural equation model (SEM) techniques. SEM is a multivariate data analysis technique that combines the measurement model which aims to provide the specification of the relationship between latent variables and the indicators and the structural model which aims to provide the effect specifications between latent variables (Hair, Babin, Anderson, \& Black, 2018).

\section{RESULTS AND DISCUSSION}

The results of this research can be seen in the following figure:

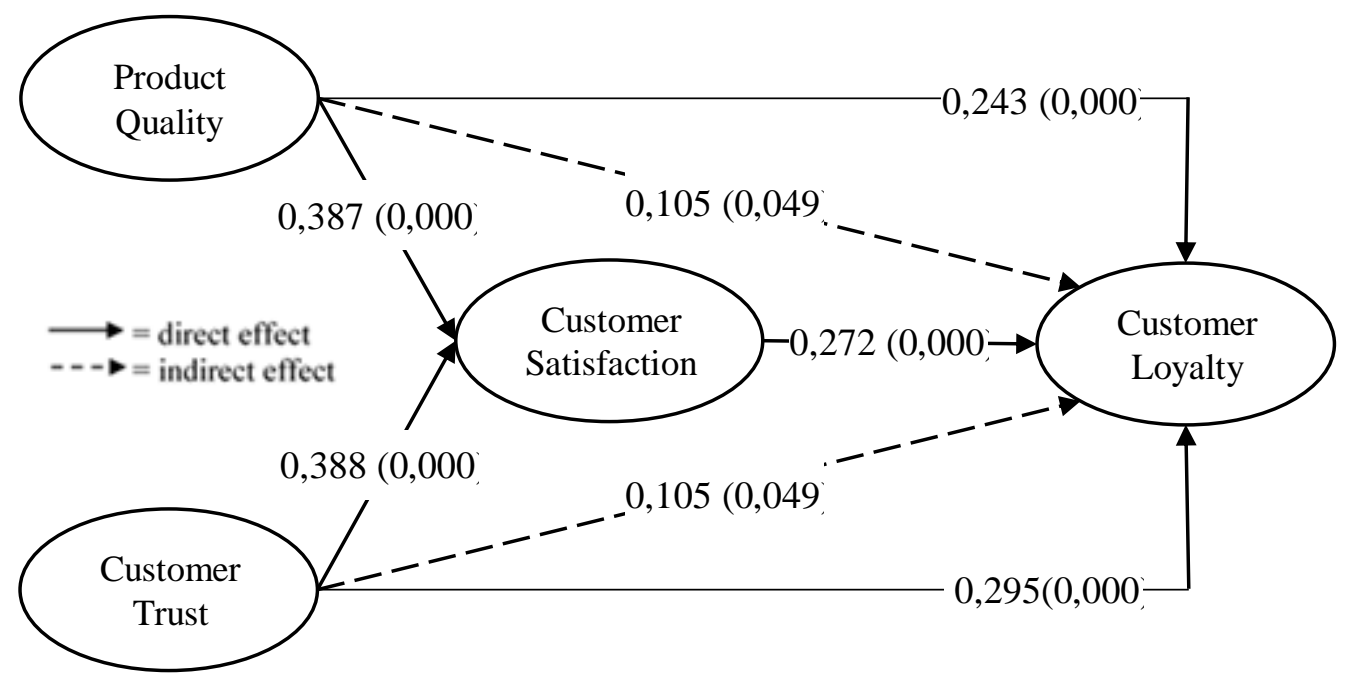

Figure 1. Results

Based on Figure 1, the discussion of the effects of P-Quality, C-Trust, C-Satisfaction, and C-Loyaltywill be further discussed as follows:

\section{Hypothesis 1 : P-QualityAffectingC-Satisfaction}

Based on the results, P-Qualitysignificantly affected C-Satisfaction with path coefficient 0.387 


\section{International Journal of Business Management and Economic Review}

Vol. 4, No. 01; 2021

ISSN: 2581-4664

and significant value 0,000 so it can be saidthatP-Qualityhas asignificant contribution in increasingC-Satisfaction by $38.7 \%$. The results showed that the P-Quality is a factor that can determine C-Satisfaction where the results indicatethatthe better the quality of the products offered by PT. Bank Aceh SyariahJantho Branch, C-Satisfaction with the bank will also increase.This result is also following the research by(Wandi et al., 2020)which also found that PQualityhad a significant effectonC-Satisfaction.

\section{Hypothesis 2 : C-TrustAffectingC-Satisfaction}

Based on the results, C-Trustsignificantly affected C-Satisfaction with path coefficient 0.388 and significant value 0,000 so it can be saidthatC-Trusthad asignificant contribution in increasingCSatisfaction by $38.8 \%$. The results showed that the C-Trustwas a factor that can determine CSatisfaction where the results indicatethatthe higher the level of C-Trusttoward PT. Bank Aceh SyariahJantho Branch, C-Satisfaction with the bank will also increase.This result is also following the research by(Hidayat et al., 2015)which also found that C-Trusthad a significant effectonC-Satisfaction.

\section{Hypothesis 3 : P-QualityAffectingC-Loyalty}

Based on the results, P-QualitysignificantlyaffectedC-Loyalty with path coefficient 0.243 and significant value 0.000 so it can be saidthatP-Qualityhad asignificant contribution in increasingC-Loyalty by $24.3 \%$. The results showed that the P-Qualitywas a factor that can determine C-Loyaltywhere the results indicatethatthe better the quality of the products offered by PT. Bank Aceh SyariahJantho Branch, C-Loyalty with the bank will also increase.This result is also following the research by(Elidawati et al., 2018)which also found that P-Qualityhad a significant effectonC-Loyalty.

\section{Hypothesis 4 : C-TrustAffectingC-Loyalty}

Based on the results, C-TrustsignificantlyaffectedC-Loyalty with path coefficient 0.295 and significant value 0.000 so it can be saidthatC-Trusthad asignificant contribution in increasingCLoyalty by $29.5 \%$. The results showed that the C-Trustwas a factor that can determine CLoyaltywhere the results indicatethatthe higher the level of C-Trusttoward PT. Bank Aceh SyariahJantho Branch, C-Loyaltywith the bank will also increase.This result is also following the research by(Majid, 2013)which also found that C-Trusthad a significant effectonC-Loyalty.

\section{Hypothesis 5 : The C-SatisfactionAffectingC-Loyalty}

Based on the results, C-SatisfactionsignificantlyaffectedC-Loyalty with path coefficient 0.272 and significant value 0.000 so it can be saidthatC-Satisfactionhad asignificant contribution in increasingC-Loyalty by $27.2 \%$. The results showed that the C-Satisfactionwas a factor that can determine C-Loyaltywhere the results indicatethatthe higher level of satisfaction felt by customers towardPT. Bank Aceh SyariahJantho Branch, C-Loyaltywith the bank will also increase.This result is also following the research by(Afeshat \& Alola, 2018)which also found that C-Satisfactionhad a significant effectonC-Loyalty.

\section{Hypothesis 6 : P-QualityAffectingC-Loyalty through C-Satisfaction}

Based on the results, P-QualitysignificantlyaffectedC-Loyaltythrough C-Satisfactionwith a path 


\section{International Journal of Business Management and Economic Review}

Vol. 4, No. 01; 2021

ISSN: 2581-4664

coefficient of 0.105 and significant value 0.049 so that the better the quality of the products offered by PT. Bank Aceh SyariahJantho Branch, C-Satisfaction with the bank will also increasewhere it is indirectly also has a significant contribution in increasing C-Loyaltyby $10.5 \%$.

Based on the results, it is known that C-Satisfaction in this researchacted as a partial mediation between the effect of P-Quality on C-Loyalty, it is seen from the resultsfound that PQuality had a significant effect on C-Loyaltyboth directly and indirectly through C-Satisfaction. This result is also following the research by(Sirait et al., 2020) which also found that CSatisfaction mediates the effect of P-Quality on C-Loyalty. However, the results of this researchhave differences with the research by(Sirait et al., 2020) where the difference lies in the role of mediating C-Satisfaction variables, in research (Sirait et al., 2020) the C-Satisfaction variable acted as a perfect mediation while in this researchC-Satisfaction variables acted as partial mediation.

\section{Hypothesis 7 : C-TrustAffectingC-Loyalty through C-Satisfaction}

Based on the results, C-TrustsignificantlyaffectedC-Loyaltythrough C-Satisfactionwith a path coefficient of 0.105 and significant value 0.049 so that it the higher the level of C-Trusttoward PT. Bank Aceh SyariahJantho Branch,C-Satisfaction with the bank will also increasewhere it is indirectly also had a significant contribution in increasing C-Loyaltyby $10.5 \%$.

Based on the results, it is known that C-Satisfaction in this researchacted as a partial mediation between the effect of C-Truston C-Loyalty, it is seen from the resultsfound that CTrusthas a significant effect on C-Loyaltyboth directly and indirectly through C-Satisfaction. This result is also following the research by(Aprilia et al., 2020) which also found that CSatisfaction mediated the effect of C-Truston C-Loyalty. However, the results of this researchhave differences with the research by(Aprilia et al., 2020) where the difference lies in the role of mediating C-Satisfaction variables, in research (Aprilia et al., 2020) the CSatisfaction variable acted as a perfect mediation while in this researchC-Satisfaction variables acted as partial mediation.

\section{CONCLUSION}

The results proved that P-Quality significantly affected C-Satisfaction; C-Trust significantly affected C-Satisfaction; P-Quality significantly affected C-Loyalty; C-Trust significantly affected C-Loyalty; C-Satisfaction significantly affected customers loyalty; P-Quality significantly affected C-Loyalty through C-Satisfaction, and; C-Trust significantly affected CLoyalty through C-Satisfaction. In the model, the C-Satisfaction acted as a partial mediator for both independent variables in affecting the C-Loyalty. These findings make a positive contribution to the development of science, especially in the field of marketing science. The novelty of the research lies in the combination of causality theory so that it becomes a model in this study. Further research should be able to further develop this tested research model, by adding moderate variables such as religiosity or type of work (businessman or not), which are an interesting issue in the use of Bank Aceh Syariah.The findings of this model are also useful as a reference for regulators at Bank Aceh Syariah. To increase consumer loyalty, Bank Aceh Syariah should improve P-Quality and consumer confidence, to increase the level of consumer satisfaction so that it has an impact on their loyalty to Bank Aceh Syariah. 


\section{International Journal of Business Management and Economic Review}

Vol. 4, No. 01; 2021

ISSN: $2581-4664$

\section{REFERENCES}

Afeshat, R. Al, \& Alola, U. V. (2018). Investigating the Nexus of Service Quality and Customer Loyalty in Banking Industry via the Mediating Role of Customer Satisfaction. Academic Journal of Economic Studies, 4(3), 167-176.

Aprilia, L., Maming, J., \& Pakki, E. (2020). The Influence Of Trust And Service Quality On Loyalty Through Customer Satisfaction At State-Owned Banks In Makassar City. Hasanuddin Journal of Applied Business and Entrepreneurship (HJABE), 3(1), 36-48. https://doi.org/https://doi.org/10.26487/hjabe.v3i1.295

Elidawati, Yasri, \& Idris. (2018). The Effect of Service Quality, Product Quality and Customer Satisfaction on Customer Loyalty of Bank Nagari Main Branch Padang. Conference: First Padang International Conference On Economics Education, Economics, Business and Management, Accounting and Entrepreneurship (PICEEBA 2018), 138-145. https://doi.org/https://doi.org/10.2991/piceeba-18.2018.41

Hair, J. F., Babin, B. J., Anderson, R. E., \& Black, W. C. (2018). Multivariate Data Analysis (8th Ed.). London: Pearson.

Hidayat, R., \& Akhmad, S. (2016). An Integrated Model of Customers' Satisfaction and Loyality: A Business Analysis of Banking Service. MIMBAR : Jurnal Sosial Dan Pembangunan, 32(1), 139-147. https://doi.org/https://doi.org/10.29313/mimbar.v32i1.1710

Hidayat, R., Akhmad, S., \& Machmud, M. (2015). Effects of Service Quality, Customer Trust and Customer Religious Commitment on Customers Satisfaction and Loyalty of Islamic Banks in East Java. Al-Iqtishad - Jurnal Ilmu Ekonomi Syariah, VII(2), 151-164. https://doi.org/10.15408/ijies.v7i2.1681

Iqbal, M. A., Murni, Y., \& Sulistyowati, N. (2018). Analysis of The Influence of Brand Image And Customer Value on Customer Satisfaction And Its Impact on Customer Loyalty. International Journal of Economics, Business and Management Research, 2(4), 343-355.

Kotler, P., \& Keller, K. L. (2018). Marketing Management, Global Edition (15th editi). Harlow, United Kingdom: Pearson.

Ling, C. H., \& Mansori, S. (2018). The Effects of Product Quality on Customer Satisfaction and Loyalty: Evidence from Malaysian Engineering Industry. International Journal of Industrial Marketing, 3(1), 20-35. https://doi.org/10.5296/ijim.v3i1.13959

Lubis, P. H. (2015). The Impact Of Service Personal Value Towards Customer Loyalty At Islamic Banking In Aceh. Journal of Economic Science, 1(1), 32-52.

Majid, R. (2013). Customer Trust as Relationship Mediation Between Customer Satisfaction and Loyalty At Bank Rakyat Indonesia (BRI) Southeast Sulawesi. The International Journal of 


\section{International Journal of Business Management and Economic Review}

Vol. 4, No. 01; 2021

ISSN: $2581-4664$

Engineering And Science, 2(5), 48-60.

Munari, L., Ielasi, F., \& Bajetta, L. (2013). Customer satisfaction management in Italian banks. Qualitative Research in Financial Markets, 5(2), 139-160. https://doi.org/https://doi.org/10.1108/QRFM-11-2011-0028

Oghojafor, B. E. A., Ladipo, K. A. P., Ighomereho, O. S., \& Odunewu, A. V. (2014). Determinants of Customer Satisfaction and Loyalty in The Nigerian Telecommunications Industry. British Journal of Marketing Studies, 2(5), 67-83.

Ridwan, B. M., Moeljadi, Sunaryo, \& Sudjatno. (2017). Influence of service and satisfaction towards customer's loyalty: a study in state-owned Islamic bank in Makassar, Indonesia. Russian Journal of Agricultural and Socio-Economic Sciences, 1(61), 60-65. https://doi.org/https://doi.org/10.18551/rjoas.2017-01.07

Sirait, H., Lubis, A. N., \& Gultom, P. (2020). Effect of Product Quality and Service Quality towards Loyalty through Customer Satisfaction at the Taplus BNI Medan Petisah Sub Branch. International Journal of Research and Review, 7(6), 202-208.

Sugiati, T., Thoyib, A., Hadiwidjoyo, D., \& Setiawan, M. (2013). The Role of Customer Value on Satisfaction and Loyalty (Study on Hypermart's Customers). International Journal of Business and Management Invention, 2(6), 65-70.

Utami, S. (2015). The Influence of Customers' Trust on Customer Loyalty. International Journal of Economics, Commerce and Management, III(7), 638-653.

Wandi, Y., Zainal, V. R., Arafah, W., Subagja, I. K., \& Saad, R. A. J. (2020). The Effect of Service and Product Quality on Customer Satisfaction through Customer Awareness of Islamic Banks In West Sumatera, Indonesia. Human \& Social Sciences Reviews, 8(1). https://doi.org/https://doi.org/10.18510/hssr.2020.8182

WeiMeng, H. (2019). The mediation effect of customer satisfaction in the relationship between product quality and customer loyalty in the banking industry, Malaysia. International Journal of Scientific \& Engineering Research, 10(5), 664-678. 